\title{
Dopady kvalitativních změn v charakteru rizik na problém asymetrie informace na pojistných trzích $^{\#}$
}

\author{
Eva Ducháčková* - Jaroslav Daňhel ${ }^{* *}$
}

\section{Úvod}

Udílení Nobelovy ceny za ekonomii na počátku nového tisíciletí Švédskou akademií věd, nejprve třem americkým ekonomům Akerlofovi, Spenceovi a Stiglitzovi za soubor prací na téma analýza trhů s asymetrickými informacemi a následně psychologovi Khanemanovi za integraci psychologického výzkumu do ekonomie zejména v souvislosti s lidským ekonomickým uvažováním a rozhodováním, významně oživilo diskusi na do značné míry kontroverzní téma chování a rozhodování ekonomických subjektů v nejistých podmínkách. Tím byla také znovu intenzivněji otevřena související otázka, zda kvůli asymetrii informace mezi aktéry směny či z jiných psychologických aspektů rozhodování v nejistých podmínkách dochází k narušení spontaneity tržního řádu, snížení efektivnosti či dokonce selhání trhu a vzniku nedokonalé konkurence s následnými nutnými intervencionistickými konsekvencemi.

Míra neúplnosti zobrazení stavů světa v lidském vědomí je mimo jiné charakteristická pro rozhodovací problémy, týkající se finančních trhů a zejména pak jejich součásti - pojistných trhů. Pomocí zkoumání asymetriíe informace na pojistném trhu je možno ověřit dosti závažnou tezi, a to, zda na něm $\mathrm{v}$ důsledku lepší informovanosti jednoho $\mathrm{z}$ účastníků pojistného obchodu (klienta pojišstovny) dochází k tzv. negativnímu výběru neboli k adverzní selekci, anebo dokonce k morálnímu hazardu, kdy činnost lépe informované strany pří maximalizaci svého užitku snižuje užitek ostatních účastníků tržní transakce, tedy ostatních klientů i pojišt'ovny.

Laureát Nobelovy ceny profesor Stiglitz je krystalickým představitelem názoru, že na pojistném trhu se asymetrie informací projevuje analogickým způsobem, jako na trhu bankovním, tedy tak, že potenciální klient pojišt'ovny je zpravidla lépe informován o své rizikovosti než pojišt'ovna a že tudíž informační převaha je na straně poptávky po pojištění. Přijetí takového názoru ve svém výsledku znamená, že vlivem adverzní selekce jsou z trhu vytlačovány kvalitnější statky, v daném prrípadě žádoucí spotřebitelé pojištění, statky méně kvalitními, tedy nežádoucími spotřebiteli.

Na téma nedokonalosti informací na pojistných trzích ovšem existují další názorové koncepce, protipólem předpokladu poptávkové asymetrie je interpretace informační výhody

\# Článek byl zpracován jako jeden z výstupů výzkumného projektu Analýza globálních trendi̊ ve světovém v českém komerčním pojištovnictvi registrovaného u Grantové agentury České republiky pod číslem 402/05/0893.

Doc. Ing. Eva Ducháčková, CSc. - docentka; Katedra bankovnictví a pojišstovnictví, Fakulta financí a účetnictví, Vysoká škola ekonomická v Praze, nám. W. Churchilla 4, 13067 Praha 3; <duchack@vse.cz>.

** Prof. Ing. Jaroslav Daňhel, CSc. - vedoucí katedry, profesor; Katedra bankovnictví a pojištovnictví, Fakulta financí a účetnictví, Vysoká škola ekonomická v Praze, nám. W. Churchilla 4, 13067 Praha 3; $<$ danhel@vse.cz>. 
na straně pojišt'ovny, tedy na straně nabídky, setkat je možno se i s tezí o oboustranně informačně asymetrickém trhu, eventuálně o symetricky informačně nedokonalém trhu.

Podstata pojištění a pojišt'ovnictví je těsně spjata se stochastickými procesy, které ještě více komplikují a současně i více zdůrazňují problém míry dokonalosti informací na tomto trhu, čímž se tento tržní segment odlišuje od jiných determinističtěji určených trhů.

Na pojistném trhu má totiž oboustranná nedokonalost informací svůj původ na prvním místě v tom, že rozhodující parametry škodního průběhu pro pojištovny i jejich klienty volí náhodný generátor, který není objektivně poznatelný pojišt'ujícím se individuálním ekonomickým subjektem a v prrísně exaktním pojetí ani pojištovnou, která při kalkulaci ekvivalentního pojistného musí vycházet z minulých dat, tedy z minulých podmínek, které se ovšem v čase mění. Tyto minulé podmínky se zatím žádnému pojistnému matematikovi do budoucnosti „rozhýbat“ nepodařilo a lze skepticky předpokládat, že se to ani v budoucnosti nepodař́i.

Z tohoto nejobecnějšího úhlu pohledu je, dle našeho názoru, pro pojistný trh charakteristická závažná oboustranná informační nedokonalost ohledně nastoupení stavu světa majícího za následek nahodilou událost s negativním finančním důsledkem pro oba účastníky pojistného obchodu, odtud je odvozována názorová variace o asymetricky oboustranně informačně nedokonalém trhu.

\section{Stiglitzova interpretace asymetrie informace na pojistných trzích s výhodou na straně poptávky}

V duchu své koncepce o informační asymetrii ve prospěch klienta pojišt'ovny Stiglitz předpokládá, že pojišt’ovny nedisponují dostatečnými informacemi o rizikovosti svých klientů, tedy že výhoda plynoucí z asymetrie informací je na straně poptávky. Stiglitz k tomu říká doslova: „Osoba, zřizující si pojištění, ví víc o tom, jaká je u ní pravděpodobnost, že bude mít nehodu (zná své řidičské schopnosti), než může vědět pojišt’ovací agent." Stiglitz (2001)

Doporučení Rothschilda a Stiglitze (1976), které by mělo vést ke zlepšení pozice pojišt'ovny na trhu s tímto hypotetickým typem asymetrie informace spočívá logicky v opatření na straně nabídky: pojišt’ovny jednotlivým klientům nabídnou různé kombinace výše pojistného a výše spoluúčasti na případné škodě. Klient si tedy může vybrat platit méně a v případě škody se na ní smluvenou spoluúčastí podílet, anebo zvolí variantu platit vysoké pojistné a v př́ípadě škody dostat plné odškodné. Podle autorů pak mechanismem sebeselekce pojišsěných prostřednictvím těchto takto strukturovaných podnětů dojde k rovnováze, tj. klienti si podle „své rizikovosti“ zvolí takovou pojistku s pojistným a spoluúčastí, která je nakonec $\mathrm{z}$ hlediska tarifní rovnováhy akceptovatelná i pro pojišt'ovnu.

Stiglitz s Rothschildem zavedli v intencích této myšlenkové konstrukce dva typy rovnováhy na pojistném trhu: tzv. sloučenou a oddělenou rovnováhu. Ve sloučené rovnováze nabízí pojišt'ovna jediný unifikovaný typ produktu, který svou konstrukcí (např. jednotnou vysokou spoluúčastí na škodě) zvýhodňuje pojišt’ovnu a klienty s nízkým rizikem a naopak znamená nevýhodu pro pojištěné s vyšším rizikem. V podmínkách oddělené rovnováhy se modelově zjednodušeně ze strany pojišstovny nabízejí dva výše charakterizované základní typy pojistek, klienti s nízkým rizikem si mohou koupit pojištění s vysokou spoluúčastí na škodě a nízkým pojistným a více rizikoví klienti si naopak mohou koupit pojištění s plným 
krytím škod a tomu odpovídajícím podstatně vyšším pojistným. A každý z těchto dvou segmentů má svou vlastní pojistně-technickou a tudíž i tarifní rovnováhu.

\section{Kritické poznámky k Stiglitzově pojetí a řešení asymetrie informace na pojistných trzích}

K tezi že individuální ekonomický subjekt - potenciální klient - má nad pojištovnou informační převahu ohledně míry své vlastní rizikovosti, je ovšem možné mít dosti vážné výhrady. V tradičních myšlenkových konceptech je poptávka po pojištění vysvětlována tím, že klienti pojišstovny (podle empirických výzkumů je to rozhodující většína lidí) mají tzv.averzi k riziku, tedy preferují jistou malou ztrátu (pojistného) před možností velké ztráty (škody), zatímco postoj pojišt'ovny vůči riziku je považován za neutrální. Ti z možných klientů pojišt'ovny, jejichž averze k riziku je nižší a blíží se neutrálnímu postoji, nemají zájem o pojištění za pojistné, které přesahuje jimi subjektivně očekávanou hodnotu škody, tj. chtějí platit pojistné jen ve výši, kterou lze z jejich subjektivního úhlu pohledu považovat subjektivně za přiměřenou.

Rozhodovací situace individuálního ekonomického subjektu ohledně pojištění je spojena s jeho subjektivním chápáním této modelové konfliktní situace, faktorů, které tuto situaci determinují, subjektivním posuzováním nejistot a vyjadřováním preferencí. Snahou teoretických př́stupů k rozhodovací analýze je dosažení vzájemné konzistence všech těchto subjektivních aspektů. Rozhodovací analýza se v tomto ohledu pokouší začlenit subjektivní ohodnocení problému a úsudky rozhodovatele do formálního modelu nikoliv tedy jako objekt reality, ale tak, jak jej chápe individuální ekonomický subjek s cílem pomoci mu získat, anebo alespoň neztratit. Výsledky řešení jsou pak značně závislé na představách a preferencích těchto subjektů.

Nebezpečími ohrožený individuální ekonomický subjekt má možnost volby ze dvou základních stategií. První, pasivní alternativou je možnost realizace negativních finančních důsledků nahodilosti ze strany ekonomického subjektu zcela ignorovat (princip totální ignorance). Tato alternativa $\mathrm{v}$ př́padě realizace negativních finančních důsledků pro ekonomický subjekt znamená újmu na majetku, eventuálně finančních zdrojích, nebo krácení ekonomických potřeb.

Druhou, aktivní alternativou je proti eventuálním finančním ztrátám z nahodilosti zapojit metody vědní discipliny risk management, která doporučuje transfer závažných, ze strany ekonomického subjektu nepředvídatelných negativních finančních důsledků na pojišt'ovnu. Do této varianty je tudíž zahrnována i uvážená kombinace řešení finančních důsledků vlastními zdroji a pojištěním. Tato druhá možnost znamená pro ekonomický subjekt každopádně ztrátu pojistného, návratnost této investice nastane jen $v$ prŕípadě realizace negativních finančních důsledků nahodilosti. Pro ekonomický subjekt se v rámci této alternativy tudíž popsaný rozhodovací problém transformuje na problém porovnání možné ztráty z titulu realizace negativních finančních důsledků nahodilosti a ztráty vzniklé zaplacením pojistného.

Klasifikace problému jako model rozhodování při nejistotě znamená pro ekonomický subjekt znalost klíče, podle jakého náhodný mechanismus volí finanční důsledky nahodilosti a znalost seznamu „rozhodnutí“ tohoto náhodného mechanismu. Hlavní úskalí z hlediska uspořádání rozhodovací problému mají ovšem ta pojištění, kde je třeba brát v úvahu možnost katastrofální škody, kterou není možno apriori kvantifikovat. Tím přestává mít ekonomický 
subjekt představu o seznamu „rozhodnutí“, které proti němu náhodný mechanismus použije a rozhodovací problém se z oblasti nejistoty posouvá do oblasti neurčitosti (blíže viz Daňhel, 1990).

Použijeme-li pro podporu rozhodnutí model hry dvou hráčů z nichž jeden je indiferentní k výši své výhry (náhodný mechanismus generující škodní průběh), lze rozbor rozhodovací situace provést pomocí kriterií, užívaných k řešení problému rozhodování při „úplné neznalosti“ (blíže Luce - Raiffa, 1957), pak z aplikace modelu teorie her plyne pro individuální ekonomický subjekt velmi silné doporučení nahradit riziko velké ztráty jistotou malé ztráty; tedy zvolit strategii uzavřít pojištění.

Rozhodovací situace individuálního ekonomického subjektu ohledně strategie pojistit se nemá povahu rozhodování při riziku, ale spíše při nejistotě, či neurčitosti Smyslem rozhodovací analýzy je doporučení takového rozhodnutí, které je nejkonzistentnější ze všech subjektivních aspektů. Výsledky řešení problému pojistit se či nikoliv jsou z výše uvedených důvodů závislé na názorech, představách a preferencích těchto individuálních ekonomických subjektů. Doporučeními rozhodovací analýzy ovšem zřejmě nebyl uspokojen „,patologický optimista“, exaktní analýzou lze ověřit, že ani jedno z používaných kriterií není schopno splnit všechny rozumné požadavky, které na ně byly položeny ve formě axiomů demiurgů vědní discipliny teorie her Luceho a Raiffy (1957).

Cestou k řešení takto postavené úlohy je zkoumání, kterým aspektům rozhodovací situace dávají ekonomické subjekty přednost a které pomíjejí jako irelevantní. Konkrétní rozhodnutí subjektu v konkrétní situaci představuje deskriptivní hledisko, optimální rozhodnutí v dané situaci, které nutně nemusí být totožné se subjektivním postojem rozhodovatele, představuje normativní hledisko. Deskriptivní hledisko objasňuje základní rysy chování subjektu, normativní hledisko dává doporučení, jak rozhodovat.

$Z$ výsledných doporučení aplikace teorie her tedy nelze $v$ tomto prŕípadě vyvozovat normativní implikace. Deskriptivně možno silné doporučení strategie pojistit se interpretovat tak, že jestliže subjekt neví nic o povaze svého „protivníka“, pak obava z neznalosti objektivních pravděpodobností, se kterými náhodný mechanismus své strategie volí, eventuálně obava z neznalosti seznamu volených strategií (katastrofálních škod) jej povede $\mathrm{k}$ rozhodnutí zabezpečit se proti důsledku nahodilosti pojištěním.

Rozhodovacími komponenty jsou často i prvky z „měkkých“ oborů psychologie (práce laureáta Nobelovy ceny Khanemana), sociologie, atd. Každý subjekt má svůj individuální vztah k situacím, kdy důsledky rozhodnutí (výši ztráty) volí náhodný mechanismus a má pro tyto situace svou individuální funkci užitku (preferenčních relací).

Pokusné zjištování individuálních preferencí či averzí k riziku naznačuje, že obecně subjekty dávají spíše přednost jisté malé ztrátě před možností velké ztráty, což dává odpověd' na kardinální otázku, zda proti nahodilým nebezpečím uzavřít pojištění a vysvětluje, proč se lidé pojištují, ač z normativního hlediska dávají přednost účasti v jevu nebo pokusu s nižší střední hodnotou výhry (komerční pojišt'ovna z vybraného pojistného musí zaplatit všechny škody a ještě své náklady správní režie a navíc vydělat). Formální model, podporující tyto úvahy na khanemanovské téma, navrhl již svého času David Bernoulli a lze jej nalézt včetně kritiky v Daňhel (1977).

Třeba ještě diskutovat už do jisté míry podružnější otázku rozsahu pojistného krytí, napřr. sjednání vyšší či nižší spoluúčasti na nastalé nahodilé škodě. Jsme názoru, že individuální 
ekonomický subjekt se pro určitý typ pojistného krytí a s tím spojenou rozdílnou výši pojistného vedle eventuálního subjektivního posuzování své vlastní rizikovosti rozhoduje spíše podle míry své rizikové averze či rizikové preference, ale i podle své aktuální finanční situace (funkce užitku) v době sjednávání pojištění, vysokou spoluúčast na eventuálně škodě může sjednat i proto, že na kvalitnější pojistnou ochranu mu prostě nevycházejí finanční prostředky. Navíc vědní disciplina risk management doporučuje ekonomickému subjektu zabezpečit se pojištěním proti finančním důsledkům takových škod, které svou výší znamenají narušení jeho finanční stability, k úhradě drobných škod pak doporučuje využít jeho vlastní zdroje.

Je tedy k Stiglitzově závěru ohledně hypotetické sebe-selekce třeba nejméně připustit námitku, že výše popsaným reliefem obsahu pojistné smlouvy podle výše spoluúčasti na škodě provedli klienti subjektivní sebe-selekci na slupiny více, či méně rizikově averzní a také na více, či méně finančně silné, eventuálně i na ty, kteří se rozhodli se chovat podle normativního doporučení vědní discipliny risk management, což je ovšem něco zcela jiného, než stanovení objektivní kvantitativní charakteristiky, exaktně měřící rizikovost klienta. Ostatně sám Stiglitz považuje klientovu informaci o míře své vlastní rizikovosti za exogenní a neměřitelnou (?!) charakteristiku. Tvrzení, že vhodně zvolené typy pojistných smluv dokáží potenciální klienty rozdělit na rizikové a bezpečné tudíž považujeme vintencích výše uvedených úvah za ne plně odůvodněné, anebo alespoň silně zjednodušené.

V této souvislosti lze Stiglitzovu modelu vytknout i jeho statičnost, v praxi pojišt'oven je běžné postupné poznávání rizikovosti klienta v čase a používání tekoucí kategorie dynamického upravování „fair" pojistného např.poskytováním slev na pojistném za nižší než kalkulovaný škodní průběh a naopak přirážek k základnímu pojistnému za vyšší škodovost (systém bonus malus) atd. Poznávání rizikovosti klienta v čase může dokonce skončit až výpovědí pojištění a zařazení až př́liš rizikového klienta na černou listinu pojištoven.

\section{Argumenty ve prospěch konceptu asymetrie informace na pojistných trzích na straně nabídky}

Obsahem analogického rozhodovacího problému pojišt’ovny je správné stanovení výše pojistného, vyjadřující apriorní pravděpodobnost finančních ztrát z realizace nahodilosti. Míra informace mezi individuálním subjektem a pojišt’ovnou je $z$ tohoto úhlu pohledu evidentně rozdílné kvality, za zcela zásadní považujeme fakt, že pojišt'ovna může k matematickému řešení svého problému (kalkulačního modelu) přistoupit jako ke zkoumání hromadného jevu. Může tudíž efektivně využít posteriorních pravděpodobností minulých negativních realizací, přitom soubor pojištěných bývá dostatečně velký pro uplatnění statistických zákonů velkých čísel (pro vzájemné vyrovnávání rizik). I přes již zmíněnou výhradu ohledně platnosti minulých podmínek, za kterých posteriorní charakteristiky škodního průběhu vznikly, pro budoucí období, je situace obou účastníků pojistného vztahu v tomto ohledu nesrovnatelná, informační převaha je dle našeho názoru zcela jednoznačně na straně pojišt’ovny.

Nutno ještě připomenout, že pojišt'ovna má ve svých statistikách minulých škodních průběhů již zohledněn fakt, že obecně soubor pojištěných proti určitým nebezpečím obvykle není standardním statistickým souborem, ale souborem rizikovějším. Do pojištění mají tendenci více vstupovat klient, které se subjektivně cítí více ohroženi finančními dopady projevů nahodilosti, např. v souboru pojištěných důchodovým pojištěním se méně vyskytují ti, kteří se z důvodu horšího zdravotního stavu nedožívají vyššího věku, ve stylu Stiglietzovy argumentace je v souboru kmene pojištění motorových vozidel více těch, kteří se necítí být 
zcela povolaní k řízení motorového vozidla, než je jejich podíl ve standardním statistickém souboru. Na tento jev, zvaný antiselekce rizik, pojišt'ovny tradičně reagují vhodnou pojistněmatematickou úpravou kalkulačního modelu. I na tomto místě je třeba zopakovat, že tento, výhradně subjektivní pocit klienta nelze objektivně exaktně kvantifikovat, tedy označit takovouto míru rizikovosti nějakým skalárem a tudíž jej lze jen stěží považovat za relevantní projev asymetrie informace.

Problém má ovšem, kromě těchto objektivních stránek daných stochastickou podstatou rozhodování tohoto typu, i svou morální stránku. Jde o klienty, kteří jsou rozhodnuti na pojištění v každém prrípadě profitovat. V těchto souvislostech je ovšem třeba nejprve položit otázku, jestli morální hazard a negativní výběr tohoto druhu, proti kterému se pojišstovna různými konstrukcemi pojistných produktů a výlukami z pojištění uvedenými v pojistných podmínkách brání, je ještě asymetrií informace ve stylu individuální informace klienta o tom, jaká je míra jeho rizikovosti. Jestliže totiž v mysli klienta definitivně uzraje myšlenka na kamufláž škody, tedy na pojistný podvod, pak již jde o jev, který nastane jistě, není tedy nahodilé povahy a jako takový nemůže být obsahem pojištění a nelze jej ani posuzovat v rámci obvyklých měřítek pojistného vztahu. Kardinální obecná otázka, zda asymetrie informace představuje zneužití či využití informace $\mathrm{v}$ rámci dobrovolného smluvního tržního aktu v takovém kontextu zcela ztrácí svůj smysl. Adekvátní je tudíž i řešení ze strany pojišstoven, pokud se o podvodu dozvědí: dotyčný subjekt vedle možných trestních konsekvencí nedostane náhradu a navíc bude zapsán na černou listinu pojištoven, čímž se stane napříště nepojistitelným.

Hlavními a asi i rovnocennými důvody pro omezení výběru individuálních subjektů co se týče pojistných podmínek konkrétních produktů jsou pojistně-technické (kalkulační) potřeby vyrovnání rozptylu v nedostatečně homogenních souborech pojištěných proti určitým nebezpečím a opatření proti nežádoucímu chování klientů ve smyslu morálního hazardu a negativního výběru.

\section{Dopady kvalitativních změn $v$ charakteru rizik na problém asymetrie informace na pojistných trzích}

V našich dosavadních úvahách jsme vycházeli z předpokladu, že většina potenciálních klientů pojišt'ovny má averzi k riziku, což zakládá motiv rozhodnutí pojistit se proti negativním důsledkům nahodilosti. Učinit takové rozhodnutí pak dále posiluje závěr risk management analýzy pro ekonomický subjekt, podle jejíhož doporučení je třeba na pojišt'ovnu přenést rizika, která mohou mít za následek škody, ohrožující finanční stabilitu subjektu, tedy zejména riziko velkých až katastrofálních škod. Dalším výchozím předpokladem úvah byl postoj $\mathrm{k}$ riziku ze strany pojišt'ovny, který byl v souladu s dosavadními myšlenkovými konstrukcemi považován za neutrální.

Podíváme-li se na tuto tezi z pohledu vědní discipliny risk management, pak důsledná neutralita vůči riziku by měla pojištovnu vést k přijímání do pojištění všech negativních důsledků nahodilosti, zejména pak těch, které hrozí katastrofální realizací. Již při zběžném pohledu na konstrukci produktů zjistíme, že tomu tak není. Komerční způsob provozování pojištění nutí pojištovny řešit svůj rozhodovací problém ohledně správné výše pojistného za poskytnutý transfer rizika $v$ rovině ekvivalenci mezi příjmy a náklady a musí se tudíž snažit co nejvíce omezit „nákladovou neurčenost“. Historickými nástroji k tomu jsou výluky tzv. elementárních rizik z pojištění (zemětřesení, výbuch sopky, ničivé tsunami apod.) a stanovení horní hranice pojistných plnění, čímž si pojišt'ovny výrazně zjednoduší svůj rozhodovací 
problém, na druhé straně se však takový pojistný produkt dostává do př́krého rozporu s požadavkem risk management na transfer velkých až katastrofálních rizik.

Trend snižování „nákladové neurčenosti“ ze strany pojišt’oven zesílil zejména v současné globalizační epoše, ve které prožívá světové komerční pojišt'ovnictví dramatickou situaci, v mnohém představující pověstný medicínský neuralgický bod. Mnozí analytici zastávají názor, že pojistné trhy jsou svou kapitálovou vybaveností nejslabším článkem současných, již tak dost rozkolísaných finančních trhů. K tomuto stavu vedle důsledků vyšší produkční schopnosti lidské společnosti, technického a technologického a také více zranitelného pokroku, souvisejícího s obrovským nárůstem (pojištěného) bohatství hlavně v západních ekonomikách, vedly zejména tyto důvody:

- splasknutí cenové bubliny na kapitálových trzích v druhé polovině devadesátých let minulého století; předchozí stav umožnil pojištovnám realizovat vysoké zisky z operací na finančním, zejména kapitálovém trhu a tím i v konkurenčním boji jednak stlačit tarify, tzv. cashflow underwriting, pod mez postačitelnosti a jednak do jisté míry i rozvolnit striktnost pojistných podmínek vedoucí k vyšší míře morálního hazardu - negativa této strategie se již na přelomu milenia projevila ve výsledovkách pojištoven červenými čísly,

- závažná eskalace škodních průběhů neživotních druhů pojištění z titulu velkých př́rodních katastrof, prakticky současně se ztrátou výkonnosti kapitálových trhů,

- závažné změny v charakteru do té doby do pojištění bez větších problémů zahrnovaných rizik, znamenající v mnohém ohledu novou kvalitu nejistoty.

Zejména druhý a třetí faktor staví pro světové pojišt'ovnictví do značné míry zcela nové a v některých prrípadech i velmi obtížně řešitelné problémy. Nejzávažnějším jevem tohoto druhu byl určitě teroristický útok 11. záríi 2002 na Spojené státy. Zborcení budov Světového obchodního centra mělo před 11. zářím pravděpodobnost nula. Analýza risk management s nebezpečím útoku civilním letadlem nemohla počítat a tudíž toto potenciální riziko nemohlo být ani apriori identifikováno. Přitom výsledkem události byly enormní ztráty na životech a zdraví a materiální škody, které znovu silně otř́sly již předtím tradičními faktory oslabeným světovým pojistným trhem.

Jinou variací na toto téma je meteorology ohlášená trvalá změna $\mathrm{v}$ distribuci vodních srážek na Zeměkouli, zejména $\mathrm{v}$ Americe a $\mathrm{v}$ Evropě a $\mathrm{z}$ toho plynoucí skok $\mathrm{v}$ časové řadě statistik amerických hurikánů a evropský povodní. Další variací na téma závažné změny charakteru rizika je výskyt nových, předtím neznámých smrtelných chorob typu SARS, BSE, ptačí chřipky apod.

Obecně neuralgičnost současného stavu komerčního pojišt'ovnictví je tedy možno spatřovat v souběhu volatilního chování finančních trhů s živelními katastrofami a projevy nové kvality rizik. Dochází k prohlubování následujícího klíčového dilema: na straně jedné se pojistitelé obávají nastoupení nových negativních jevů dosud nepoznané povahy, které při své rizikové analýze nemohli nepředpokládat, ale jejich eventuální důsledky při tradičním (nerozvolněném) výkladu pojistných podmínek jsou kryty pojištěním. V podnikové ekonomice pojišt’ovny tudíž vyvíjejí maximální snahu o snižování vlastních nákladů a o optimální řízení podnikových aktiv a pasiv. Postoj pojišt’oven k riziku se stále více odklání od čisté rizikové neutrality směrem k averzi k riziku, jako předpoklad fungování komerčního pojišt'ovnictví se jeví právo pojišstoven odmítnou pojištění rizika, které nelze apriori 
identifikovat. $\mathrm{V}$ tomto ohledu nutno brát $\mathrm{v}$ potaz $\mathrm{i}$ deskriptivní hledisko, nebot' tyto rozhodovací problémy ovlivňuje i postoj (averze) k riziku vedoucích pracovníků pojistitele.

$\mathrm{Na}$ straně druhé klienti hledají v cenově dostupných produktech pojišt'oven finanční ochranu proti možnému nastoupení nepředvídatelných jevů nových nebezpečí a s ohledem na poslední události tohoto druh ve světě u většiny lidí stoupá míra riziková averze. Růst pojistných tarifů a selekce rizik přijímaných do pojištění a zpř́ísňování pojistných podmínek pak vede klienty k hledání alternativních forem financování rizika. Vyšší míra angažovanosti je pak poškozenými očekávána ze strany veřejných financí

Až doposud byl problém trhu s asymetrií informací zkoumán v modelu, ve kterém existovaly pouze dva subjekty pojistného vztahu, a to pojištěný a pojistitel. V reálné ekonomice však do těchto tržních interakcí zasahují vlády jako regulátor trhu se snahou o jeho stabilizaci. Vlády mohou prostřednictvím veřejných financí zajišt’ovat obzvláště velká katastrofická rizika, poskytují pomoc při ztrátách, at' už materiální nebo finanční, popř. poskytují obětem škod nízko úročené půjčky.

Vládní podporu je možno považovat za substitut komerčního pojištění založeného na tržních základech. Př́tomnost vládních transferů (podpory) může jak snížit určitou poptávku po pojištění, tak na ni za určitých podmínek nemusí mít zcela žádný vliv. V těchto úvahách hraje rozhodující roli míra rizika, které nese daný pojištěný subjekt. Vládní dávky jsou obvykle vypočítávány až po tom, co bylo veškeré pojistné plnění v prŕípadě vzniku ztráty vyplaceno, proto lze konstatovat, že koupě takového stupně pojistné ochrany, která by v případě vzniku škody zaručovala naprosto shodné plnění s vládní podporou by bylo nadbytečné a naprosto neefektivní. Poškozený subjekt by tak obdržel plnění i bez koupě pojištění.

$\mathrm{Na}$ druhou stranu je třeba říci, že kdyby cena pojistného byla z pojistně matematického pohledu férová (s absencí správních nákladů a zisku pojišt'ovny), subjekt by raději preferoval plné pojistné krytí s absencí jakýchkoliv vládních subvencí. Ekonomický subjekt se v tomto prípadě rozhoduje mezi minimálním pojistným krytím poskytovaným vládou za nulové pojistné nebo platbou pojistného komerčním pojišt'ovnám oplátkou za plné pojistné krytí.

V případě vládních pomocí při realizaci rozsáhlých škod jde vždy o politická rozhodnutí, což obvykle vede k nerovnoměrnému a nespravedlivému rozdělování transferů. Spotřebitelé, kteří pojišt'ují svůj majetek jsou tak "potrestáni“ za svou racionální volbu koupě pojistného. Naopak ti, kteří spoléhají výlučně na vládní podpory jsou za jinak stejných podmínek zvýhodňováni. Pakliže bude vládní transferová politika př́liš štědrá a nebude tržně konformní, bude to mít za následek upřednostňování transferu před komerčním pojištěním. To pak nebude schopné plnit svou funkci stabilizátoru ekonomiky a v prípadě vzniku rozsáhlých škod pak mohou tyto škody z makroekonomického hlediska brzdit ekonomický růst, popř. způsobit recesi. Je patrné, že tím, kdo je v př́ípadě př́liš štědré a tržně nekonformní transferové politiky vlády poškozeným na trhu s existencí nedokonalé informace na straně poptávky je více rizikový spotřebitel. Pro tohoto spotřebitele není úvaha o substitutu ve smyslu vládního transferu, úvahou racionální a reálnou, resp. ji nezařazuje do svého seznamu preferencí.

Důležitým principem při využívání pojištění je právě důsledné vyhýbání se antiselekci rizik, tedy adversní selekce, což je obecně tendence intenzivnějšího sjednávání a využívání pojištění subjekty, jejichž míra rizika je horší než průměrná. 
Obecně angažovanost veřejných financí při alternativních formách přenosu rizika by měla vypadat takto: Namísto dosud ad hoc přijímaného řešení včetně financování na účet postižených subjektů, státu a komerčních pojišt'oven a zajišt'oven je nutno v nových podmínkách problém řešit systémově vícevrstvovým (např. běžné prostředky komerčních pojišstoven a zajišstoven, zvláštní rezervy komerčních pojištoven a zajišt'oven, státní fond na financování katastrof) finančním zabezpečením,

\section{Závěry vyplývající pro regulaci pojišt'ovnictví z problému asymetrie informace mezi klientem a pojišt'ovnou včetně dopadů kvalitativních změn v charakteru rizik}

Z výše naznačených argumentů je pro předmět našeho zkoumání implikován názor, že vodvětví pojišt'ovnictví neexistuje výraznější endogenní (kvantifikovatelná) asymetrie informace na straně poptávky, tedy na straně klienta. Naopak, na straně nabídky má pojišt'ovna svůj rozhodovací problém stanovení ekvivalentního pojistného ulehčen okolnostmi, plynoucími z přirozené (stochastické) povahy této ekonomické činnosti. Endogenní asymetrie informací je tudíž na straně nabídky. Tento fakt již sám o sobě zakládá diskusi o eventuální potřebě ochrany klienta pojištovny, zajišt'ující mu splnitelnost závazku. Jinou variací na toto téma je otázka, kam až může pojišt'ovna zajít při zjišt'ování údajů o klientovi, zvyšující její informační převahu, zpřísňování výkladu pojistných podmínek, atd.

$\mathrm{Na}$ straně nabídky může ovšem vzniknout i exogenní asymetrie informace v př́padě vstupu na trh problémového, nebo dokonce nepoctivého pojistitele. Škála nepoctivého chování je široká, počíná skrytými výlukami z pojištění v pojistných podmínkách a končí počátečním zinkasováním pojistného $\mathrm{s}$ následným odchodem $\mathrm{z}$ trhu. Odborným dozorem snížit pro neznalého klienta riziko špatného výběru se tudíž jeví jako tržně konformní.

V kontextu diskuse, zda asymetrie informace může znamenat natolik vážné selhání trhu, že je nutný externí (státní) zásah k obnově rovnováhy, nutno vzít v úvahu některé specifičnosti finační sféry a pojištovnictví zvláště. Ponechat na tržním mechanismu, jinými slovy na smithově neviditelné ruce trhu, o které Stiglitz ř́ká, že bud' neexistuje, anebo že notně zestárla, přirozené samovolné pročištování ekonomického prostředí od nezdravých finančních institucí je obzvlášt' citlivá záležitost. Krachy bank, pojištoven, penzijních fondů, investičních společností, atd. mají dalekosáhlé důsledky pro důvěru lidí v celý společenský systém a svými konkrétními dopady př́liš rozkmitávají další navazující národohospodářské obory a nakonec i celou ekonomiku. Tržně konformní regulace, jejímž hlavním úkolem je prevence nežádoucích výkyvů a snižování asymetrie informace je tudíž, dle našeho názoru, ve finanční sféře v moderní složité globální společnosti nevyhnutelná.

V rámci informační asymetrie na pojistném trhu existuje celá řada ustanovení v jednotlivých právních normách, která prrípadné negativní důsledky informační nedokonalosti regulují. V tomto př́ípadě je však na místě zdůraznit fakt, že v současné době je to více informační asymetrie na straně nabídky, kterou se jednotlivé zákony, at' už přímo či neprrímo, zabývají. Na druhou stranu však tyto zákony neopomíjejí morální riziko na straně poptávky, které je prítomno jak samotnému aktu uzavírání pojistné smlouvy, tak i uplatňování práv z pojištění.

Páteří finančních trhů jsou bezesporu trhy bankovní. Pro banky je charakteristický relativně vysoký poměr cizího kapitálu k vlastním zdrojům. Toto specifikum je charakteristické nejen pro bankovnictví, ale i pro pojišt'ovnictví, z čehož plyne obecná 
oblíbenost investic do bank, spořitelen a pojištoven, na druhé straně může být i zdrojem obtíží pro ekonomiku banky a pojišt'ovny.

Od bankovní regulace se odvíjejí některé analogie pro ostatní segmenty finančních trhů. V minulém století vznikl Basilejský výbor pro bankovní dohled jako nadnárodní instituce, která se snaží o regulaci bankovního sektoru ve směru konzistentního působení k vyššímu finančnímu zdraví a stabilitě. Po na konci osmdesátých let vydané normě Basel I bude v průběhu roku 2006 implementován současnou situaci na bankovním trhu reflektující předpis Basel II. Vnitřním obsahem trojpilírového systému je stanovením minimálních kapitálových požadavků, zlepšení práce $\mathrm{s}$ bankovními riziky, dále zpřesnění metodiky účinného státního dohledu a v neposlední řadě dodržování tržní discipliny. Implementace Basel II by měla přinést snížení míry asymetrie informace a vyšší stabilitu pro komerční bankovnictví a vyšší bezpečnost pro jeho klienty.

V pojišt’ovnictví vedle obecných argumentů ve prospěch tržně konformní regulace ve finanční sféře jsou hodným zvláštního zřetele ještě dva faktory: za prvé závislost hospodářského výsledku pojišt’ovny v neživotních druzích pojištění na konkrétním nastoupení náhodné veličiny - velikosti škodního průběhu a za druhé existence velkého časového zpoždění mezi počátkem a koncem životního pojištění, jinými slovy mezi počátkem a následným placením pojistného a výplatou pojistné částky. V průběhu tohoto období může dojít $\mathrm{k}$ na pojišt’ovně nezávislým závažným změnám v makroekonomickém okolí, jejichž dopad je žádoucí ze strany pojišt'ovny ve svém hospodaření utlumit. Pojišt'ovnictví je svou stochastickou podstatou založeno na systému rezerv, je tedy logické, že obecně je úhelným kamenem ochrany klientů pojišstoven ze strany státního dozoru určení povinnosti tvořit určité druhy rezerv a následně i normativní reglementace hospodaření pojišt'ovny s těmito rezervami. Regulace nakládání s „dlouhodobými“ penězi pojištěných normativní reglementací ukládací politiky pojištoven je i ortodoxními liberály nezpochybňovanou nutností.

Z výše uvedených tezí je zřejmé, že hledání optimální polohy tržně konformní regulace je z uvedených dvou nejdůležitějších hledisek v pojišt'ovnictví určitým problémem. Za tržně konformní je v současnosti považován tzv. nepř́ímý dozor, kdy regulatorní orgány na rozdíl od př́mého dozoru neprovádějí normativní a materiální dohled s okamžitými zjištěními a možností okamžitého opatření, ale zaměřují se na sledování finančního zdraví pojištovny

Analogií ukazatele kapitálové přiměřenosti $\mathrm{v}$ bankách je $\mathrm{v}$ oboru pojišt'ovnictví ukazatel solventnosti pojišt'ovny a analogická opatření organizovaná Evropskou komisí v rámci EU k stabilizaci pojistného trhu jsou známé pod názvy Solvency I a nyní k implementaci připravovaná Solvency II. Obdobně jako vpř́padě Basel II je připravovaná evropská direktiva další generace Solvency II postavena na třech pilíŕích: optimalizaci vlastního kapitálu (vedle minimálního kapitálového požadavku se v pojišt’ovnictví uvažuje ještě solventní kapitálový požadavek), vyšších kvalitativních požadavcích na řízení rizik a tržní disciplíně včetně požadavků na zveřejňování informací a reporting. Uniformní způsob sdělování údajů subjektům trhu a regulátorům nabídne možnost dalšího snížení informační asymetrie, lepšího porovnání s konkurencí, synergie mezi finančními a regulačními výkazy snížení nákladů na implementaci a kvalitnější a konzistentnější bázi pro oblast řízení rizik a kapitálu. Na rozdíl od Basel II, který ponechává určitou vůli národním regulátorům zabývá se jen stranou aktiv banky, Solvency II je založena na reálném ocenění aktiv i pasiv pojišt'ovny a vytváří rámec pro dlouhodobou harmonizaci finančních trhů v integrovaných uskupeních. Direktiva Solvency II je plně konzistentní s idejemi gradualizovaného konceptu Enterpise Risk Managament, v rámci kterého je tradiční Risk Management proces fragmentového pojetí rizika a jeho ad hoc rrízení nahrazován integrovaným, široce zaměřeným procesem, fungujícím 
jako nepřetržitě tekoucí kategorie, umožňující lepší porozumění pojistně-technickému, tržnímu, úvěrovému, operačnímu a likviditnímu riziku.

Komerční pojišt'ovnictví je ovšem svou podstatou a ekonomickými výsledky závislé především na k úrovni ekonomických parametrů lhostejném generátoru náhodné veličiny, který volí škodní průběh pojistných produktů. Proto vcelku nepřekvapí, že podle údajů britského integrovaného dozoru nad bankami, pojišt'ovnami a kapitálovými trhy - Financial Services Authority - představuje pojistně-technické riziko u neživotních pojistných produkti̊ $61 \%$, tedy rozhodující část problému.

Subtilní matematicko-statistické metody kvantifikace rizika zabudované do modelů Solvency II nepochybně zlepší současný stav a přinesou vyšší stabilitu a bezpečnost pojišt'ovacího byznysu a posílí důvěru klientů. To ovšem platí především pro ty neživotní produkty, které poskytují pojistné krytí pro soubor homogenních rizik s relativně nízkou variabilitou a konečným a známým rozměrem nejvyšší možné škodní události. Př́kladem za všechny může být produkt havarijního pojištění. Neuralgický bod současného neživotního komerčního pojištění je však spojen $\mathrm{s}$ faktem, že v moderním světě dochází k významným změnám v charakteru a kvalitě rizik a některé $\mathrm{z}$ těchto změn souvisejí s obtížnou apriorní identifikací a kvantifikací rizika a tím narážejí na barieru komerčního provozování pojištění proti negativním následkům nahodilosti. Problémem jsou v tomto ohledu omezené možnosti matematiky a navazujících exaktních věd, které nejsou dialektickými metodami poznání a nemohou tudíž vyřešit základní metodologický rozpor: Tarifní kalkulační modely pojištoven mohou, jak již bylo konstatováno, vycházet jen z minulých škodních průběhů, žádný pojistný matematik zatím nedokázal „rozhýbat“ tyto minulé podmínky do budoucnosti, tedy jinými slovy učinit budoucnost předmětem vědeckého zkoumání, když jako předmět ještě neexistuje. Výskyt zcela nových nebezpečí, výrazné kvalitativní změny v charakteru rizik, proti kterým pojišstovny tradičně nabízely pojistné krytí, to je, možno říci, stále přetvávající neuralgická hrozba pro světové pojištovnictví, proti které zatím nemáme exaktní prostředky. Musíme konstatovat, že případné důsledky takové hrozby nikterak nezmírňuje ani projekt Solvency II.

\section{Závěr}

Možno shrnout, že pojišt'ovnictví v současné globální éře $\mathrm{s}$ ohledem na změny v charakteru rizik se dostává do situace, kdy plné krytí velkých a katastrofálních škod z nahodiloých př́íčin podle doporučení vědní disciplíny risk management naráží na bariery komerčního způsobu fungování pojištění. Situaci dále komplikuje existence oboustraně nedokonalých informací na pojistných trzích, proto se v moderním stále více složitém světě jeví, dle našeho názoru, nezbytností tržně konformní regulace, kromě dalších efektů ochrany klienta, výrazně snižující asymetrii informace na pojistných trzích.

Nová kvalita a nový charakter některých rizik pak implikuje, že u klientů a i u pojistitelů dochází k zvyšování averze k riziku, komerční pojišstovnictví v rámci svých ekonomikou určených hranic má pro úspěšné fungování pojištění povinnost snižovat „,nákladovou neurčenost“ zaváděním limitů pojistného plnění a odmítnout pojišt'ování rizik, kde informační nedokonalost je takového stupně, že je pojišt'ovny nemohou apriori identifikovat. Lidská společnost pro ochranu před takovými nebezpečími musí hledat jiné alternativní formy přenosu rizika a jejich důsledky financovat vícevrstvově a vícezdrojově. 


\section{Literatura}

[1] Daňhel, J. (1977): Pojištění z hlediska teorie optimálního rozhodování. Ekonomickomatematický obzor, 1977, roč. 13, č. 1, s. 92-103.

[2] Daňhel, J. (1990): Is Insurance Transfer of Risk? Pojistné rozpravy, 1990, roč. 0, svazek 3, s. 3-12.

[3] Luce, R. D. - Raiffa, H. (1957): Games and Decision. New York, John Wiley, 1957.

[4] Rothschild, M. - Stiglitz, J. (1976): Equilibrium in Competitive Markets: An Essay on the Economics of Imperfekt Information. Quarterly Journal of Economics, 1976, roč. 90, č. 4, s. 629-649.

[5] Stiglitz, J. (2001): Asymetrie informací a moci. Ekonom, 2001, roč. 48, č. 50, s. 22-23. 


\title{
Dopady kvalitativních změn v charakteru rizik na problém asymetrie informace na pojistných trzích
}

\author{
Eva Ducháčková - Jaroslav Daňhel
}

\begin{abstract}
ABSTRAKT
Udělení Nobelovy ceny vědcům za teoretický př́spěvek $\mathrm{k}$ analýze trhů s asymetrickými informacemi oživilo diskuse o chování a rozhodování ekonomických subjektů v nejistých podmínkách. Protože pojišstovnictví je klasickým př́kladem takových situací, slouží $\mathrm{k}$ ilustraci př́ípadů asymetrie, u klientů pojišt'ovny je předpoklad, že znají lépe svou expozici vůč riziku než pojistitel.
\end{abstract}

Ve skutečnosti klient svou objektivní expozici nemůže apriori exaktně kvantifikovat, rozhodnutí je ovlivňováno psychologickými a sociologickým faktory. Pojistitel je lépe vybaven pro kalkulaci pojistného, zahrnující minulou zkušenost s využitím statistických zákonů s přihlídnutím $\mathrm{k}$ antiselekci rizik.

Závěrečná část článku se zabývá regulací pojistných trhů v návaznosti na asymetrii informace mezi pojišt'ovnou a jejím klientem.

Klíčová slova: Rozhodování při nejistotě; Asymetrie informace na pojistných trzích; Důsledky pro dohled.

\begin{abstract}
The Nobel Prize award to scientists for thier theoretical contribution to analysis of markets with asymmetrical informations has reawakened debates on the behavior and decision-making of economic player under uncertainty. Becouse insurance is an classic example of such a situation, it is used to illustrate the cases of asymmetry, for the clients is supposed to know better his own exposure then the insurer.

In fact, the client's objective exposure apriori be cannot quantified from the point of wiew of exact sciencis and his decision is futher influenced by psychological and sociological faktors. The insurer is better equipped to make calculations, drawing on past experience and using the laws of statistics, furtermore, he takes antiselection on account.

The final part of the paper explores the field of insurance market regulation in relation to the asymmetry of information between an insurance company and its client.

Key words: Decision under uncertainty, Asymmetric information on insurance market, Consequences for supervisory.
\end{abstract}

JEL classification: D740, D810, D820, G220 